\title{
The Correlation Between Emotional Intelligence and Subjective Well-Being Among Psychology Students in Jakarta
}

\author{
Brenda Valerie $^{1 *}$ Heni Mularsih ${ }^{1}$ \\ ${ }^{1}$ Faculty of Psychology, Universitas Tarumanagara, West Jakarta, Indonesia \\ *Corresponding Author: Email: brenda.705170235@stu.untar.ac.id
}

\begin{abstract}
This research aims to discover the correlation between emotional intelligence and subjective well-being of psychology students in Jakarta. This research used a quantitative method. The respondents of this research were 198 psychology students (174 females and 24 males) in Jakarta range in 18-25 age. This research used the sampling technique of convenience sampling. The results of the respondents' data analysis were obtained by using Pearson correlation technique on emotional intelligence and subjective well-being. The results of the correlation between the two variables show that there is a significant and positive correlation between emotional intelligence and subjective well-being of psychology students in a university in Jakarta.
\end{abstract}

Keywords: Emotional Intelligence, Subjective well-being, Psychology students, Jakarta

\section{INTRODUCTION}

According to the general director of World Health Organization, good mental health is important to overall health and well-being [18]. Mental health is a state of wellbeing in which an individual realizes their own potential, can overcome the stress of daily life, is able to work productively, and contribute to their community [19]. One of the indicators of mental health is subjective well-being [7].

Subjective well-being is an individual's judgment of the level of their positive and negative affect, and their overall evaluation of life ${ }^{[8]}$. This evaluation is an emotional reaction to an event and a cognitive judgment on happiness and life fulfillment. The concept of happiness and subjective well-being can be considered as the same, which is the thought and feeling that an individual's life is going well [2]. Diener has stated that the experts avoid using the term happiness due to the broad range of its definition. For that reason, subjective well-being is considered as a more appropriate term [2].

A high level of subjective well-being can be achieved with a combination of key elements, namely global life satisfaction, positive affect, and negative affect. Some individuals will feel happiness from these three elements, but others may only feel happiness from some elements only [2]. Long-term research also shows that the level of subjective well-being may cause a higher health status [20]. Apart from health, subjective well-being also affects an individual's income and social behavior [10]. Hence, subjective well-being has an important role in every individual's life. Based on the research about the level of subjective well-being in a group of students, it was found that $57,33 \%$ of the students were in the average and low categories [9]. Low subjective well-being in students would surely affect them negatively in their lives, such as causing anxiety, which then would cause them to have a low level of coping and motivation [11]. Therefore, it is important for students to try to improve their subjective well-being so that they can avoid the negative impacts caused by low subjective well-being.

Psychology students who specifically study mental health and subjective well-being would surely understand how to maintain their well-being. However, it is a fact that psychology students also experience mental health problems. A case that shows the importance of mental health for psychology students is Marsha M. Linehan's case. Linehan is a well-known psychologist who succeeded in discovering a therapy method that is now used worldwide for individuals who have a suicidal tendency. Linehan admitted that during her early days as a student, she used to have suicidal thoughts, and even attempted to commit suicide when she was 20 years old [1]. In addition, a survey conducted on Jovita has proved that more students of the Faculty of Psychology, Universitas X Bandung have felt negative affect than positive affect during their study. A survey observing psychology students of Unesa of 2017 batch has stated the students' level indicator of life fulfillment during their study. Most participants felt that their lives were unsatisfactory. This unsatisfactory surely has reasons, whether it is from their own behavior, or from the factor of their environment. Feeling dissatisfied, obviously, is not what people hope for, as they generally want to live a good and fulfilling life [13]. 
Subjective well-being has a strong positive correlation to social integration, which is an individual's ability to interact interpersonally and maintain the emotional balance that is part of social integration, which will increase alongside the level of subjective well-being [5]. The ability to maintain emotional balance is defined as emotional intelligence. Emotional intelligence is the ability to recognize one's and others' feelings, motivate oneself, and manage emotions of themselves and within a relationship with others ${ }^{[4]}$. An individual is considered to have high emotional intelligence if they can adaptively overcome stress and problems in daily life so that they are manageable, have a more intimate relationship, and a broader network of social support ${ }^{[21]}$. Moreover, an emotionally intelligent individual will show strong capacity to facilitate a better adaptation of a change caused by a certain condition and consider the stress as a challenge rather than a threat [17].

Furthermore, based on a meta-analytic observation by Schutte et al., [17] and Martins et al., [12] they have found a similar result, in which high emotional intelligence has a significant positive correlation to better health. The research conducted by Julika and Setiyawati also shows that academic stress and emotional intelligence contribute to students' subjective well-being [6].

More research shows that emotional intelligence is crucial in various healthy adaptation aspects, from affective function to social relationships ${ }^{[17]}$. For the past years, one of the issues that has taken the interest of researchers is the role of emotional intelligence characteristics in determining subjective well-being that refers to the way one experiences their quality of life [3].

Due to the important role of emotional intelligence in improving subjective well-being and the gaps of research, the researchers wanted to redo the research with those variables. This research is different from the previous research by the research subjects and instruments. Consequently, this research is conducted to discover and examine the correlation between emotional intelligence and subjective well-being of psychology students for the purpose of human development.

Based on the analysis of the phenomenon and urgency above, is there a correlation between emotional intelligence and subjective well-being of psychology students in Jakarta?

\subsection{Emotional Intelligence}

Emotional intelligence is defined as a rare ability to express anger to the right person, within an appropriate degree, in a proper time, and for the right purposes [4]. Emotional intelligence as human's basic ability to live: for example, the capability of controlling emotional impulse, reading others' deepest feelings, and maintaining relationships well [4].

The dimensions used in this research are: a) self-awareness, b) managing emotions c) motivating oneself. d) empathy skills, and e) handling relationship.
Self-awareness is one's ability to recognize their feelings and use it to make decisions for themselves, have a realistic standard of their capabilities and have high self-confidence. Managing emotions is one's ability to control their emotions so that it will bring a positive effect to task performance and self-awareness. Individuals who lack in this ability will keep fighting moodiness, whereas those who have this ability will be able to rise faster from the decline and fall in life.

Motivating oneself is one's ability to control their motivation so that they can be more enthusiastic and powerful to get to a better condition, and to take initiative and act effectively. Individuals who have this ability tend to be more productive and effective with their daily work. Empathy skills is one's ability to understand the emotional makeup of other people. Individuals who have empathy will be able to catch hidden and implicit social signals from others. Empathic individuals are compatible with nursing, teaching, sales, and management professions.

Handling relationship is one's ability to maintain a good relationship with other individuals. This is a social ability. Individuals who have this ability will be able to influence, lead, discuss, resolve conflicts, and work together in a team.

\subsection{Subjective Well-Being}

As defined by psychologists, subjective well-being is one's judgment toward the levels of positive and negative affect, and their evaluation of life in general [8].

The dimensions used in this research are a) positive affect, b) negative affect, and c) global life satisfaction.

Positive affect. This dimension reflects how an individual feels enthusiastic, active, and aware. High positive affect is the condition of high energy, full concentration, and enjoyable engagement, while low positive affect is indicated by sadness and lethargy.

Negative affect. This dimension is a subjective dimension which, in general, includes difficulties and unpleasant engagement that involves a condition variation of unpleasant mood, such as anger, disdain, disgust, guilt, fear, and restlessness.

Global life satisfaction. It is a subjective condition based on one's condition that is related to the feeling of content and discontent caused by the impulse or needs within themselves and correlated to the reality they experience.

\section{RESEARCH METHODOLOGY}

This research was a quantitative and non-experimental research. The characteristics of the research subjects are active students of the Faculty of Psychology of a university in Jakarta within the age range of 18-25. The selection of respondents is not limited to any specific ethnic, race, religion, or culture. The number of respondents who participated in this selection is 198 students. Based on the data obtained, most respondents are female, with a total of 174 students, whereas the number of male respondents is 24 students. 
The writers conducted the process of collecting the data for one month and online, which was in November 2020 and used Google Form with the criteria of research participants that had been determined.

\subsection{Scale of Emotional Intelligence}

Emotional intelligence used an instrument that is arranged based on five dimensions of emotional intelligence adopted from Research and Measurement Department in the Faculty of Psychology, Universitas Tarumanagara (2013). Meanwhile subjective well-being used an instrument adopted from Research and Measurement Department in the Faculty of Psychology, Universitas Tarumanagara (2008). Both instruments passed the adapted procedure of legibility test for the subject candidates, the item validity test was passed through a try out to test the validity and reliability of the questionnaire items.

After collecting the data, they were processed with IBM SPSS (Statistical Package for the Social Sciences) program, 25.0 version, to calculate the statistics. In this research, the writers are interested in observing the correlation between both variables, so, there must be a bivariate correlation analysis on the software. The purpose of correlation analysis in general is to observe the level of intensity, direction (type), and significance of the correlation between both variables.

\subsection{Scale of Subjective Well-Being}

Subjective well-being instrument comprises 48 statement items. Based on the result of reliability test, the score of alpha Cronbach coefficient of each dimensions of subjective well-being instrument is obtained. The first dimension, positive affect, has the initial score of alpha Cronbach of 0.916 . The second dimension, negative affect, has the score of alpha Cronbach of 0.918. The third dimension, global life satisfaction, has the score of alpha Cronbach of 0.836 . Hence, it can be concluded that subjective well-being instrument is reliable in consistently showing responses from subjects.

The result shows that from 48 statement items, each item has the validity score above 0.2 , so, there are no items discarded.

\section{FINDINGS AND DISCUSSIONS}

\subsection{Findings}

\subsubsection{Reliability Test}

An instrument of intelligence that consists of 43 items. Based on the result of reliability test, the score of alpha Cronbach coefficient of each dimensions of emotional intelligence instrument is obtained. The first dimension, self-awareness, has the score of alpha Cronbach of 0,704. The second dimension, managing emotions, has the score of alpha Cronbach of 0.709 , meanwhile the final score of alpha Cronbach of 0.791. the third dimension, motivating oneself, has the score of alpha Cronbach of 0.811 . The fourth dimension, empathy skills, has the initial score of alpha Cronbach of 0.815 . The fifth dimension, handling relationship, has the score of alpha Cronbach of 0.850 .

The result shows that from the 43 statement items, there are 2 items that have the score of corrected item-total correlation smaller than 0.2 , thus, those items are discarded. Therefore, the total of valid and reliable items is 41 statement items. Before conducting the hypothesis test, the researchers previously performed the classic assumption testing by using normality test on both emotional intelligence and subjective well-being variables. This normality test is useful for determining the correlation analysis technique, which is Pearson correlation (if the data are normally distributed) or Spearman correlation (if the data is not normally distributed).

\subsubsection{Normality Test}

Normality test uses one-sample Kolmogorov-Smirnov Z analysis. The result of normality test on emotional intelligence variable is $0.750 \mathrm{p}=0.628$ (> 0.05 ). Meanwhile, the normality test on subjective well-being variable is $0.735 \mathrm{p}=0.652(>0.05)$. After the normality test, it is found that emotional intelligence and subjective wellbeing variables are normally distributed. It can be seen from the score of $\mathrm{p}$ (asymptotic significance) on both variables that have a score greater than 0.05 . The result of normality test of both variables can be seen in detail on Table 3.1.

Table 1 The Result of Normality Test of Emotional Intelligence and Subjective Well-Being Variables

\begin{tabular}{|c|l|c|}
\hline Variable & $\begin{array}{l}\text { Kolmogorov- } \\
\text { Smirnov } \mathbf{z}\end{array}$ & $\mathbf{p}$ \\
\hline Emotional intelligence & 0.750 & 0.628 \\
\hline Subjective well-being & 0.735 & 0.652 \\
\hline
\end{tabular}

Based on the result of normality test, a hypothesis test was performed by using Pearson correlation analysis technique because both variable data are normally distributed.

\subsubsection{Correlation Test}

Correlation Test uses Pearson correlation analysis technique and the result shows that emotional intelligence and subjective well-being variables have a significant and positive correlation. This is indicated by the score of $\mathrm{r}(198)$ $=0.596$ and the score of $p=0.000(<0.05)$. The correlation test result of both variables can be seen in detail in Table 3.2 . 
Tabel 2 The Result of Correlation Hypothesis Test of Emotional Intelligence and Subjective Well-Being Variables

\begin{tabular}{|l|l|}
\hline & $\begin{array}{l}\text { Emotional Intelligence and } \\
\text { Subjective Well-Being }\end{array}$ \\
\hline $\mathbf{r}$ & 0.596 \\
\hline $\mathbf{p}$ & 0.000 \\
\hline
\end{tabular}

Based on the result of the correlation between emotional intelligence and subjective well-being of psychology students in Jakarta, it is found that there is a significant and positive correlation, so that the research hypothesis is accepted with the score of $\mathrm{r}(198)=0.596$ or $59,6 \%$ with the score of $p=0.000(<0.05)$. This shows that emotional intelligence variable has a correlation to subjective wellbeing of $59.6 \%$ and the remaining is related to other variables. The analysis result of both variables also has a positive correlation. Therefore, if the score of emotional intelligence variable is high, the score of subjective wellbeing variable will also be high. On the contrary, if the score of emotional intelligence variable is low, the score of subjective well-being variable will also be low.

\subsection{Discussions}

Based on the results of regression analysis, it was found that emotional intelligence and subjective well-being has significant and positive correlation. This research is in agreement with previous research by Sánchez et al., [14] and Szczygieł and Mikolajczak [17] that has stated that there is a significant and positive correlation between emotional intelligence and subjective well-being. Generally, an individual who feels, knows, and manages their emotions can overcome emotional problems better, thus, the individual will experience a higher subjective wellbeing independently from how emotional intelligence is measured [21].

In addition, this research has limitations on the imbalance of the number of male and female participants, of which there were 174 females and 24 males that can affect the result of inferential test based on gender. Moreover, the literary research was only performed online due to the COVID-19 pandemic, which forbids a visit to the library because every library enforces online operation, thus, causing this research to have a longer time to collect data as the researchers had to collect the data online.

The researchers suggest future research to have a balanced number of respondents and appropriate to the sample of research population so that the result will be representative. Moreover, future research may be performed in a longitudinal manner so the development process of subjective well-being of psychology students can be observed in a certain period of time.

In addition, the researchers recommend the future researchers who are interested in observing the same variables to correlate the emotional intelligence and subjective well-being variables to other secondary variables. Examples of variables that can be correlated are emotion regulation, mindfulness, self-efficacy, and selfesteem. Furthermore, future research may also change the research subjects so that the subject category is limited not only to students, but also to other groups to enhance future research.

\section{CONCLUSIONS}

Based on the research result that proves that there is a positive and significant correlation between emotional intelligence and subjective well-being and that emotional intelligence has a contribution of $56.9 \%$, the researchers suggest that: (1) Students need to improve their emotional intelligence by reading books or articles about emotional intelligence so their subjective well-being will also improve, (2) The school party (teachers), through the learning process, may remind the students to manage their emotions by reflecting to self and others, can empathize with the condition experienced by their peers, and (3) For future researchers to test not only the correlation between variables, but also their roles, or using Dependent Variable (DV) that is considered to have a correlation through journal study.

\section{ACKNOWLEDGMENT}

This work was supported by Faculty of Psychology, Universitas Tarumanagara. I would like to express my utmost gratitude that has facilitated and other parties that have helped so that we may participate in this conference.

\section{REFERENCES}

[1] Carey, B. (2011). Expert on mental illness reveals her own fight. The New York Times: Live Restored. Retrieved from:https://www.nytimes.com/2011/06/23/health/23lives. html

[2] Diener, E. (2017). Happiness: the science of Subjective well-being. In R. Biswas- Diener \& E. Diener (Eds), Nobatextbookseries: Psychology. Champaign, IL: DEF publishers. DOI: nobaproject.com. https://nobaproject.com/ modules/happiness-the-science-of-subjective-well-being.

[3] Diener, Ed., Lucas, RE, \& Oshi, S. (2003). Personality, Culture, and Subjective Well Being: Emotional and Cognitive Evaluation of Life. Annual Reviews. DOI: 10. 1146/annurev.psych.54.101601.145056

[4] Goleman, D. (2015). Kecerdasan emosional: Mengapa EI lebih penting daripada IQ. Jakarta: Gramedia Pustaka Utama. 
[5] Imaginario, S., Vieira, L. S., \& de Jesus, S. N. (2013). Subjective well-being and social integration of college students. Journal of Spatial and Organizational Dynamics, 1(3),215-223. Retrieved from http://www.cieo.pt/journal/ J_3/article7.pdf

[6] Julika. S., \& Setiyawati. D. (2019) Kecerdasan emotional, stress akademik, dan kesejahteraan subjektif pada mahasiswa. Gadjah Mada Journal of Psychology (GAMAJOP), 5(1), 50-59. DOI: 10.22146/gamajop.47966

[7] Keyes, C. L. M. (2006). Subjective well-being in mental health and human development research worldwide: an introduction. Social Indicators Research, 77. DOI: 10.1007/ s11205 005-5550-3

[8] King, L. (2007). The science of psychology. New York: McGraw-Hill Education.

[9] Kuaksizoglu, A., \& Topuz, C. (2014). Subjective well being levels of university students. Journal of Educational and Instructional Studies, 4(3).

[10] Lucas, R. E., \& Diener, E. (2015). Personality and subjective well- being: Current issues and controversies. In M. Mikulincer, P. R. Shaver, M. L. Cooper, \& R. J. Larsen (Eds.), APA hand- books in psychology. APA handbook of personality and social psychology: Vol. 4. Personality processes and indi- vidual differences (pp. 577-599). Washington, DC: American Psychological Association. https://doi.org/10.1037/14343-026

[11] Mukhlis, H., \& Koentjoro. (2015). Pelatihan kebersyukuran untuk menurunkan kecemasan meghadapi ujian nasional pada siswa SMA. Gadjah Mada Journal Of Professional Psychology, 1(3), 203-215

[12] Martins, A., Ramalho, N., \& Morin, E. (2010). A comprehensive meta-analysis of the relationship between emotional intelligence and health. Personality and Individual Differences, 49, 554-564. http://dx.doi.org/10. 1016/j.paid.2010.05.029.

[13] Rosyadi, A.K., \& Laksiwati, H. (2018). Hubungan antara grit dengan Subjective well-being pada mahasiswa psikologi universitas negeri Surabaya Angkatan 2017. Character: Jurnal Psikologi 5(2). https://jurnalmahasiswa. unesa.ac.id/index.php/character/article/view/23542/21519.

[14]Sánchez-Álvarez, N., Extremera, N., \& FernándezBerrocal, P. (2015). The relation between emotional intelligence and Subjective well-being: A meta-analytic investigation. The Journal of Positive Psychology, 11(3), 276-285. doi:10.1080/17439760.2015.1058968.

[15] Schneider, T. R., Lyons, J. B., \& Khazon, S. (2013). Emotional intelligence and resilience. Personality and Individual Differences, 55(8), 909-914. DOI: 10.1016/ j.paid.2013.07.460
[16] Schutte, N. S., Malouff, J. M., Thorsteinsson, E. B., Bhullar, N., \& Rooke, S. E. (2007). A metaanalytic investigation of the relationship between emotional intelligence and health. Personality and Individual Differences, (42). 921-933. http://dx.doi.org/10.1016/j. paid.2006.09.003

[17] Szczygieł, D., \& Mikolajczak, M. (2017). Why are people high in emotional intelligence happier? They make the most of their positive emotions. Personality and Individual Differences, 117, 177-181. DOI: 10.1016/j. paid.2017.05.051

[18] World Health Organization. (2020a, Januari 01). COVID-19 disrupting mental health services in most countries, WHO survey https://www.who.int/news/item/ 05-10-2020-covid-19-disrupting-mental-health-servicesin-most-countries-who-survey

[19] World Health Organization. (2020b, Oktober 30). Mental health: a state of well-being. https://www.who.int/ mental_health/who_urges_investment/en/

[20] Xu, X., Pang, W., \& Xia, M. (2020). Are emotionally intelligent people happier? A meta-analysis of the relationship between emotional intelligence and subjective well-being using Chinese samples. Asian Journal of Social Psychology. DOI: 10.1111/ajsp.12445

[21] Zeidner, M., Matthews, G., \& Roberts, R. D. (2011). The Emotional Intelligence, Health, and Well-Being Nexus: What Have We Learned and What Have We Missed? Applied Psychology: Health and Well-Being, 4(1), 1-30. DOI: 10.1111/j.1758-0854.2011.01062.x 